\title{
Intra-annual variations of intensity of subsurface currents and surface water temperature in the southwestern part of the Barents Sea inferred from drifter data
}

\author{
O. P. Nikitin ${ }^{1}$ and A. O. Zhukovskaya ${ }^{1}$ \\ Received 23 August 2016; accepted 24 August 2016; published 5 September 2016.
}

The paper presents a description of observations of near-surface currents and water temperature at the surface, made in the Barents Sea and in the south-western part of the Kara Sea with the help of satellite tracked drifting buoys - drifters. This information should be taken into account when planning further drifter observations in the considered area. For the southwestern region of the Barents Sea - the most covered by drifter observations - the intra-annual variations of the averaged velocity module of currents at the depth of $15 \mathrm{~m}$ and the average temperature at the water surface are calculated. It is shown that the currents intensify in winter and weaken in summer with a minimum of the velocity module in August. Water temperature at the surface, on the contrary, has a maximum in August, and a minimum is reached in April. KEYWORDS: drifter observations; subsurface currents; surface water temperature; annual course; Barents Sea; Kara Sea.

Citation: Nikitin, O. P. and A. O. Zhukovskaya (2016), Intra-annual variations of intensity of subsurface currents and surface water temperature in the southwestern part of the Barents Sea inferred from drifter data, Russ. J. Earth. Sci., 16, ES3004, doi:10.2205/2016ES000570.

\section{Introduction}

Currents and hydrological characteristics of the Barents Sea have been studied for over a century. The vast number of publications on currents is based on the results of calculations with the use of a dynamic method, diagnostic, prognostic, adaptation models involving observations of temperature and salinity of sea water and wind (see, e.g., [Aadlandsvik, 1989, Averkiev and Klevanny, 2010 Arkhipov and Popov, 1996, Asplin et al., 1998, Bulushev and Sidorova, 1994 Diansky et al., 2014. Ingvaldsen et al., 1999 , Semenov and Chvilev, 1996. Slagstad et al., 1989. Trofimov, 2000. Yakovlev, 1999 and literature cited there).

Direct measurements of the surface currents using oceanographic drifting buoys which are tracked by the satellites began to be carried out in the western part of the Barents Sea by the Norwegian specialists since 1981 [Loeng, 1989]. These freely drifting buoys (the so-called Lagrangian drifters) are deployed on the open water in contrast to the ice buoys, installed mainly on the ice and drifting with it (see, e.g., [Turet et al., 1993). A large number of ice buoys were deployed in the Arctic Ocean within the long-term International Arctic Buoy Program.

${ }^{1}$ N. N. Zubov State Oceanographic Institute, Moscow, Russia

Copyright 2016 by the Geophysical Center RAS.

http://elpub.wdcb.ru/journals/rjes/doi/2016ES000570-res.html
In the Russian part of the Barents Sea the launches of the modern drifters still have not been made. However, since 1992, in the considered area there are drifters appearing which were launched in the western, Norwegian part of the Barents Sea and in the Northern Atlantic. Launches are made within the framework of the Global Drifter Program (GDP), which is a component of the Global Ocean Observing System [Lumpkin and Pazos, 2007]. Data from these observations are available on the GDP website.

This work gives the characteristic of the observations of currents and water temperature, carried out in the Barents Sea and in the south-western part of the Kara Sea by means of the GDP drifters in the period of January 1992March 2016.

\section{Drifting Buoys Measurements in the Barents and Kara Seas}

Figure 1 shows the map of start points of GDP drifters and end points of their drift in the Barents Sea (part of the drifters completed its drift in the south-western part of the Kara Sea).

End points of a drift indicate that the drifter ceased to transmit information (e.g., due to the voltage drop on the battery), or was taken out of the water (e.g., by fishermen), or was run aground by currents. As seen from Figure 1 about a half of drifters finished their drift on the coast of 


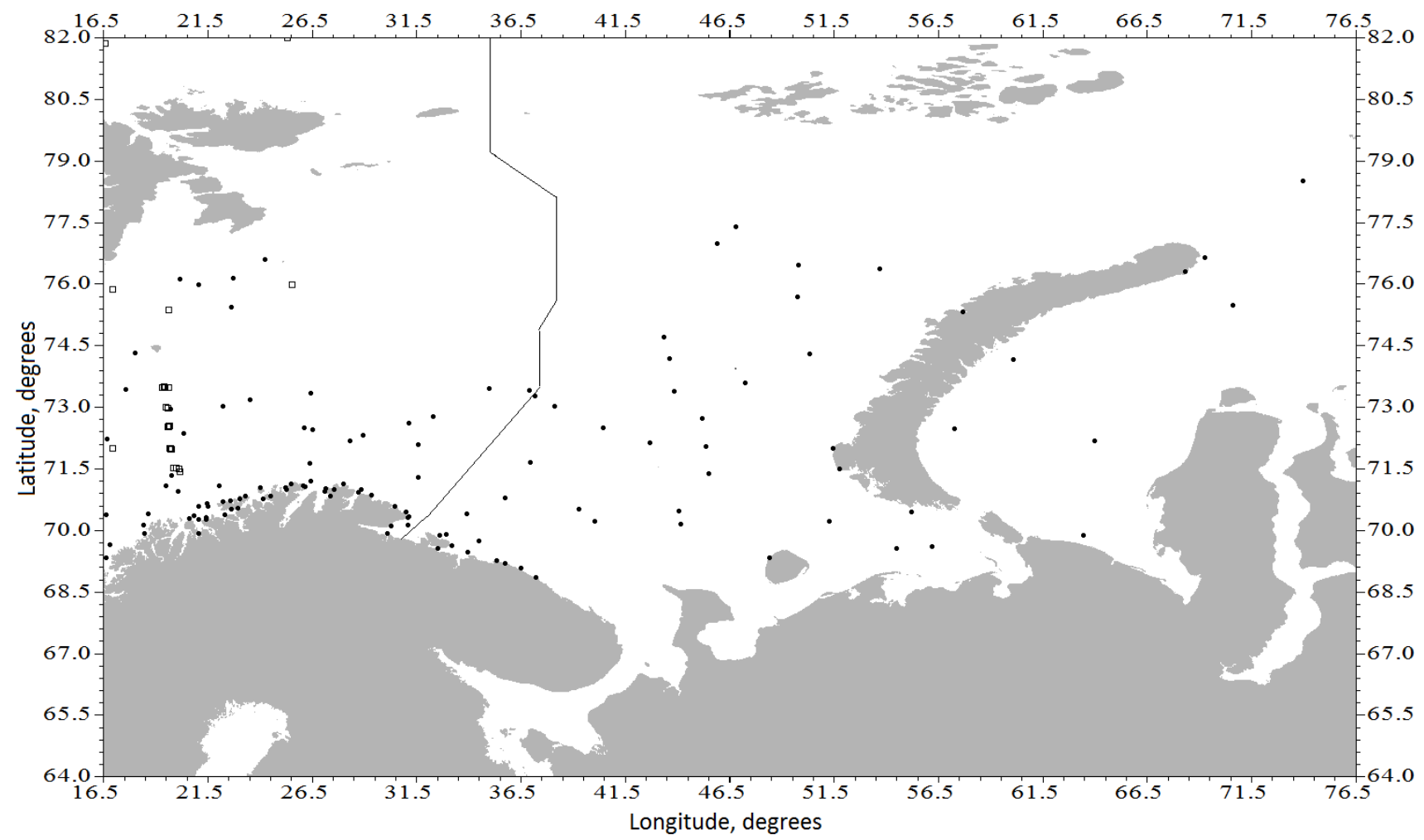

Figure 1. Initial (small squares) and end (black dots) positions of GDP drifters in the Barents and Kara Seas in the period of 1992-2016. The line of demarcation between the water areas of Russia and Norway in the Barents Sea is specified.

Norway and the Kola Peninsula. There's also to be expected a severe clutter caused by the ejection of debris to the shore which floats on the surface of the Barents Sea (containers, plastic bottles, bags, and so on).

A few start points are located to the west of the broken line of the maritime boundary between the Norwegian and Russian parts of the Barents Sea, which runs in the meridians range from 31 to $38^{\circ} \mathrm{E}$ (Figure 1). Most of drifters was deployed out of the Barents Sea, with some of them drifted from far away.

Figure 2 shows the trajectory of the drifter Argos no. 83427, which had been launched in the Irminger Sea in the North Atlantic, crossed meridian $31^{\circ} \mathrm{E}$ in more than two years later and then made a closed circulation counterclockwise in the Barents Sea during more than one year.

According to the data obtained from the GDP website, in total 158 drifters swam away from the West to the Barents Sea during the period from 1992 to 2016, many of which appeared in the Russian part of the sea (Figure 3.

Generally speaking, carrying out the marine scientific researches in the territorial waters and the exclusive economic zone of the Russian Federation by the Russian and foreign organizations requires to obtain a permission from the Ministry of Education and Science of the Russian Federation according to the established rules (Government of the Russian Federation, On endorsing the rules of conducting marine scientific research in the inland sea waters, territorial sea, exclusive economic zone and on the continental shelf of the Russian Federation, Decree No. 3912004, 2004). However, observations by means of the GDP drifters are carried out without such permissions. Foreign organizations, which carry out such research, motivate it by the fact that the launching of drifters takes place outside the zone of jurisdiction of the Russian Federation, and after the launch of drifters they move into the uncontrolled mode. Facts of crossing the sea border of the Russian Federation in the Barents Sea by foreign drifters can be treated as violation of its sovereignty. However, since domestic drifting buoys observations are not made, and the GDP data are available for use over the Internet, the attitude of the authors of the present article to the observations in the Barents and Kara seas by means of the GDP drifters is rather positive.

It is quite another matter if not all GDP data for the considered area of the Arctic seas are in the open access a question for which the authors have no answer at present. However, it is known that a part of the data in the GDP database has a signature stamp "Restricted" and therefore is inaccessible for wide use. Not infrequently the owners of the data, which launched drifters, do not provide data in free public use and it is necessary to address directly to them for the data. For example, on the GDP website in open access there are less than $40 \%$ of the drifting buoys data for the Black Sea in relation to the volume that was eventually collected by the authors of the present article, and there are 


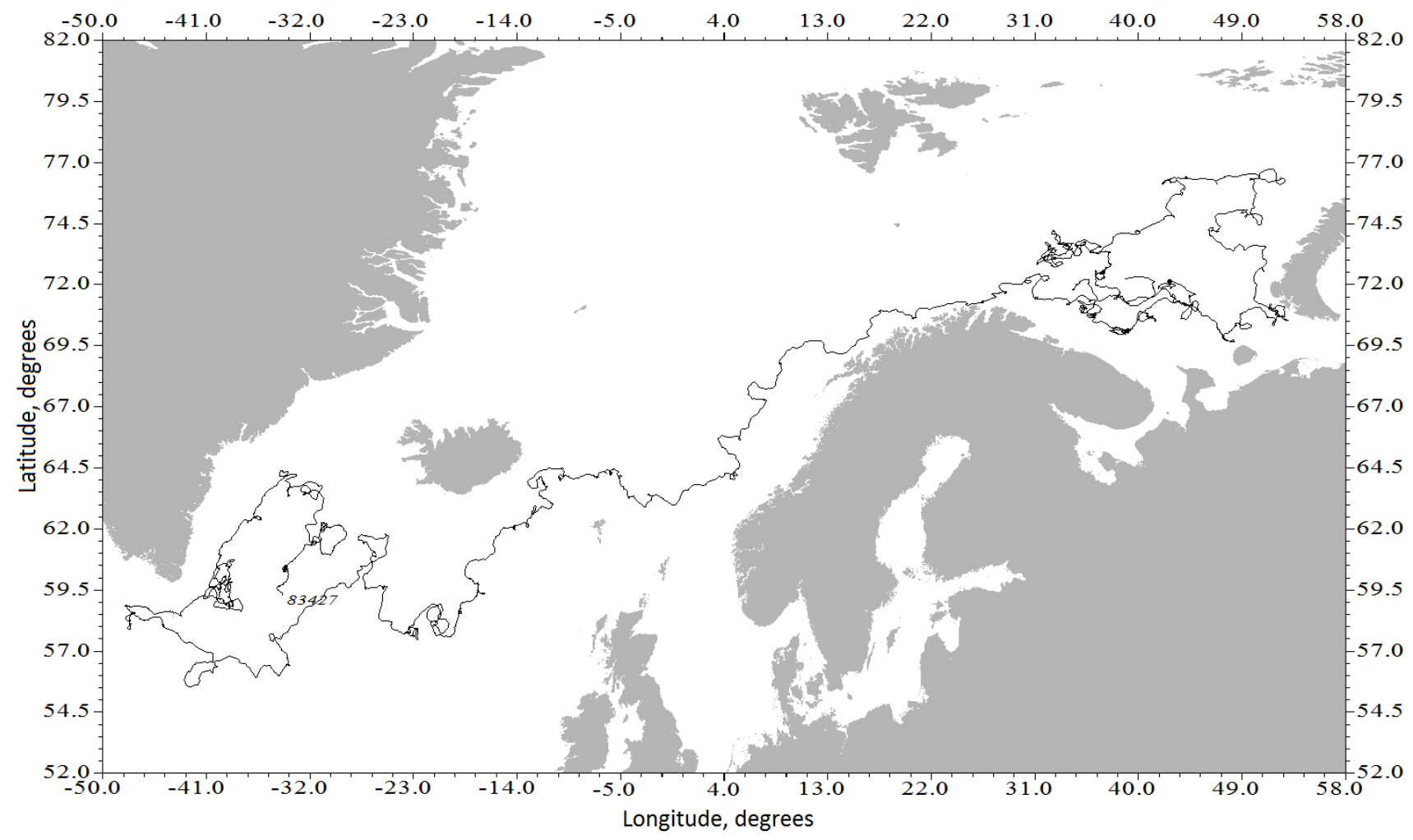

Figure 2. Trajectory of the GDP drifter Argos no. 83427 in the North Atlantic. The beginning of the trajectory is noted by the number of the drifter.

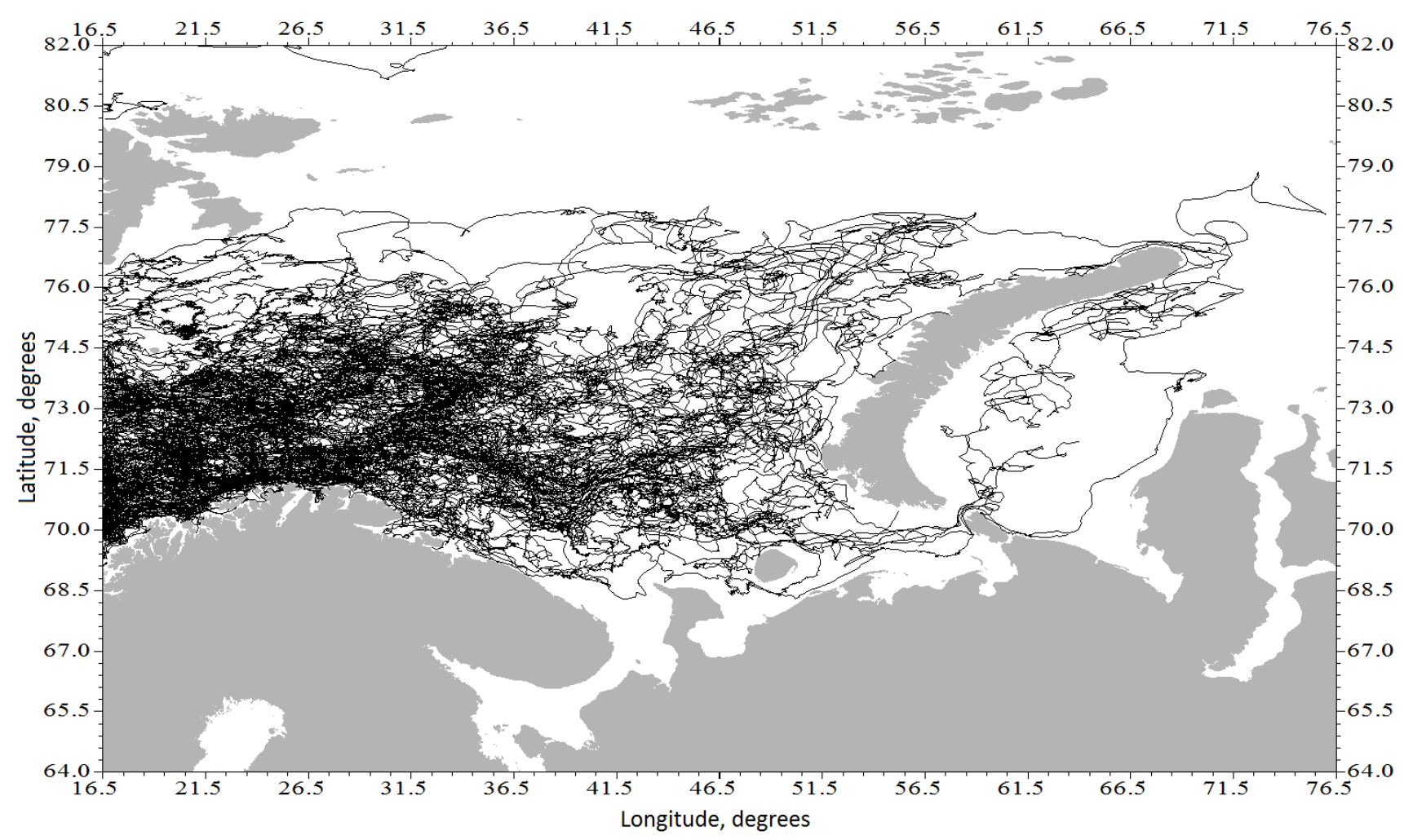

Figure 3. Trajectories of drifters in the Barents and Kara Seas during 1992-2016. 


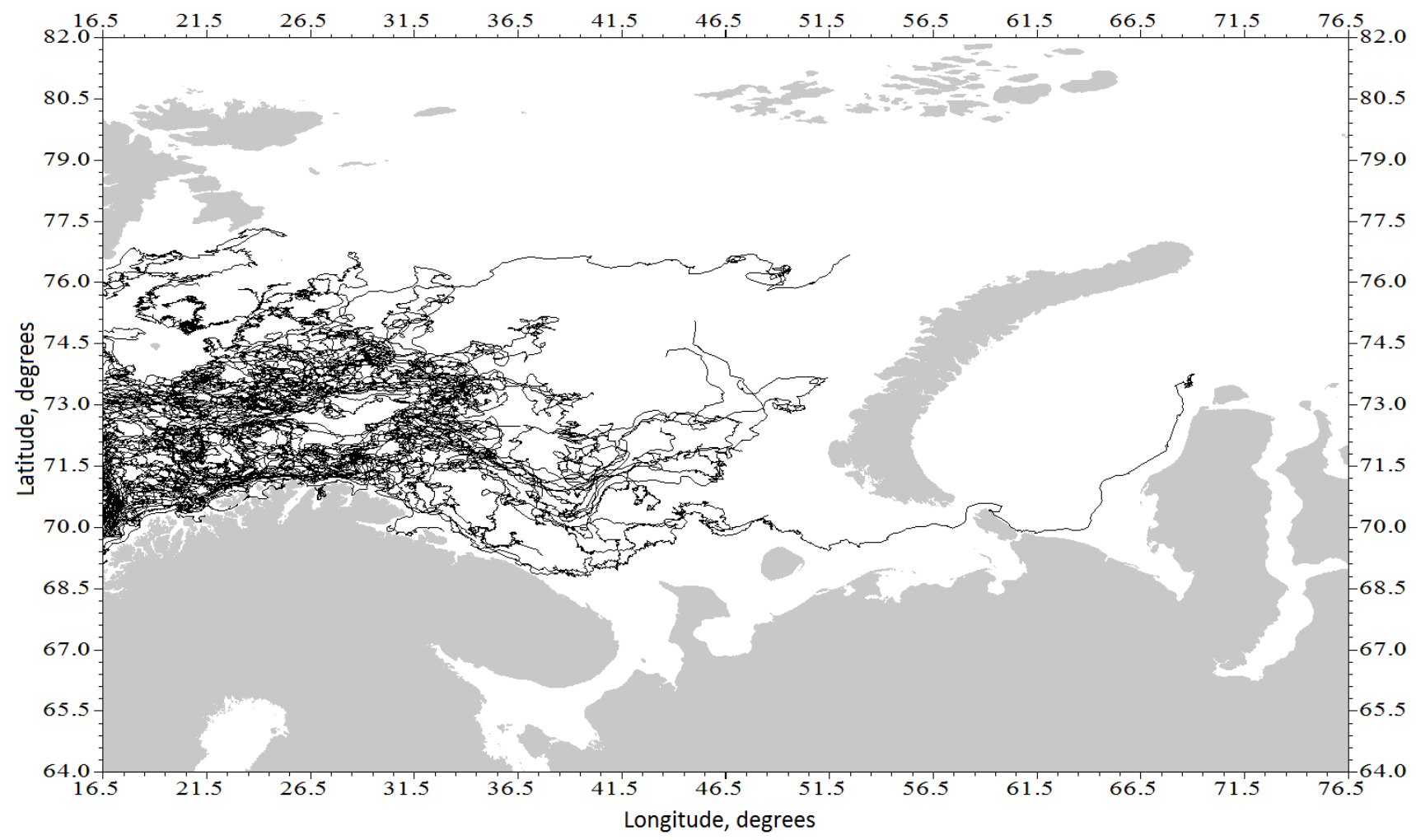

Figure 4. Trajectories of drifters with drogues in the Barents and Kara Seas during 1992-2016.

no data for the Caspian Sea though the Lagrangian drifting buoys there were launched.

The Lagrangian drifter of the GDP standard consists of the surface spherical buoy (float) of a small size (from 30.5 to $40 \mathrm{~cm}$ in the diameter) and the underwater anchor-saildrogue in the form of a cylinder of relatively big size (from 61 to $92 \mathrm{~cm}$ in diameter and from 3.68 to $6.44 \mathrm{~m}$ in length) which is connected with the buoy by a cable. Its center is located $15 \mathrm{~m}$ below the water surface. On the surface buoy there are batteries, a satellite radio transmitter, a sensor of presence/lack of a drogue and a thermistor, located at the base of the buoy. Other measuring instruments of hydrometeorological parameters can also be installed [Lumpkin and Pazos, 2007.

Locations of the drifter are monitored from satellites; the data on trajectory of the drifter then get to the world centers of acquisition. Velocity of the surface current is determined by a simple dividing of the distance between two satellite fixings of position of the drifter on time interval between them.

An underwater drogue considerably minimizes the impact of surface waves and wind on the drifter. A number of comparisons of estimates of surface currents velocity received by the drifters with and without a drogue, showed that drifters without a drogue can move faster than drifters with a drogue by up to $9-10 \mathrm{~cm} / \mathrm{s}$ at a velocity of wind of $10 \mathrm{~m} / \mathrm{s}$ [Grodsky et al., 2011. Pazan and Niiler, 2001, Reverdin et al., 1994. Therefore, velocities determined by data of drifters without a drogue, without adjustments for wind and wave factor can be overestimated.
During a drift the underwater drogue often comes off and after its loss the data of the current velocity, generally speaking, should be rejected. At the same time, the quality of the data of water temperature at the surface does not depend on presence or absence of the drifter drogue. The analysis of metadata about the movement of drifters which trajectories are represented in Figure 3 showed that $58 \%$ of drifters had a loss of a drogue. In Figure 4 trajectories of drifters before loss of a drogue are represented.

In the present work the data of the current velocity after a separation of a drogue were rejected. Therefore, a map shown in Figure 3 characterizes the coverage of the considered water area by drifter observations over water temperature and the map shown in Figure 4 - over currents. Obviously, many water areas are poorly or not at all covered by drifter observations.

Calculations showed that the mean time of a drift of drifters in the considered water area without taking into account the presence of a drogue (Figure 3) was 199 days, maximal - 923 days. Drift time before loss of a drogue in the considered water area (Figure 4 varied from 1 to 542 days and the mean time was 130 days.

The maps shown in Figure 3 and Figure 4 give an idea of the distribution of drifter observations over space, and the maps shown in Figure 5 and Figure 6 , characterize the coverage of the considered area by drifter observations also by months of year.

Figure 5 shows the distribution of the number of months of the year over cells of the grid with steps $2^{\circ}$ on longitude and $1^{\circ}$ on latitude in which at least one determination of 


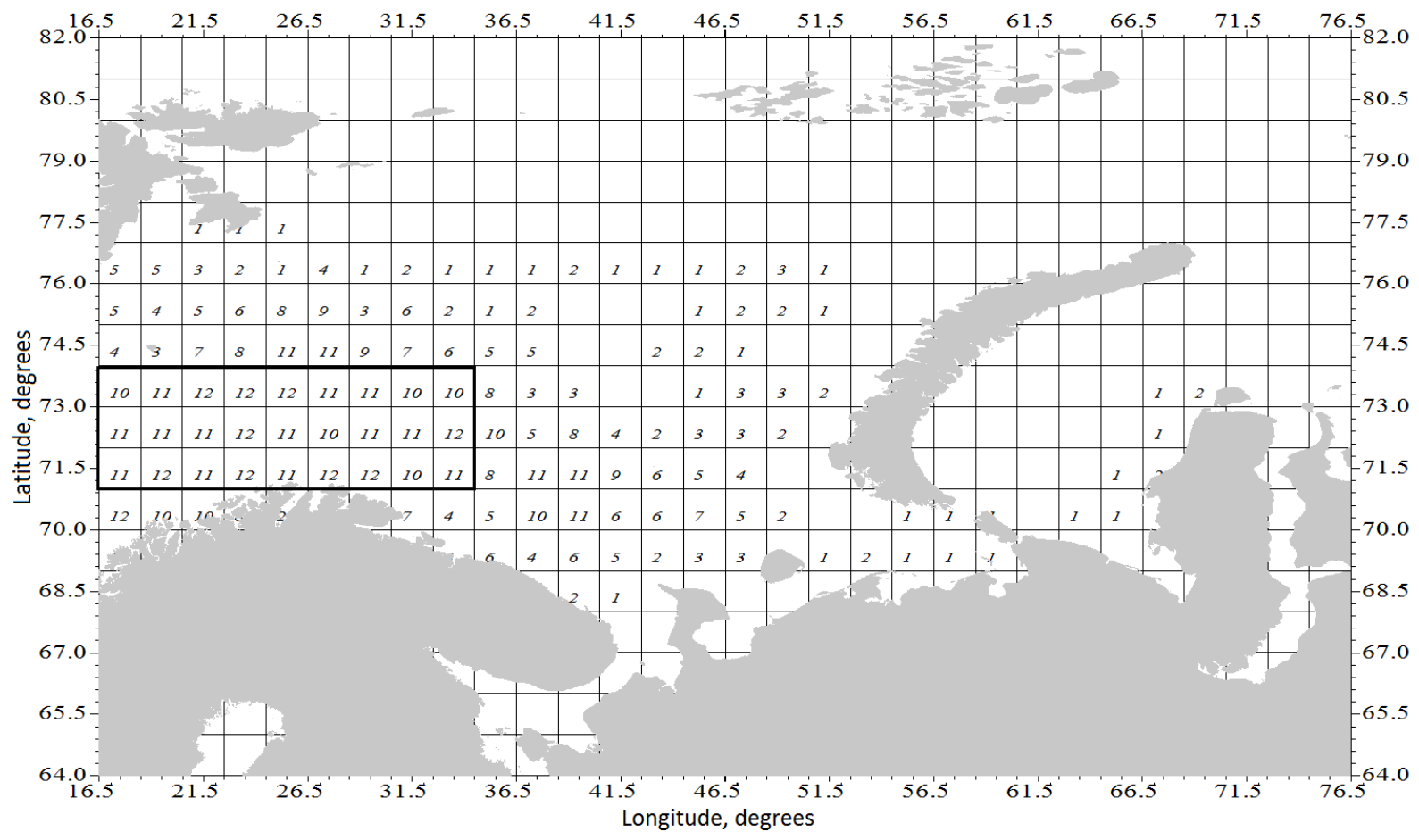

Figure 5. The number of months of year in which the determination of velocity vectors of currents in grid cells with steps $2^{\circ}$ on longitude and $1^{\circ}$ on latitude were carried out. The frame specifies the region for calculation of the intra-annual variation of velocity of currents.

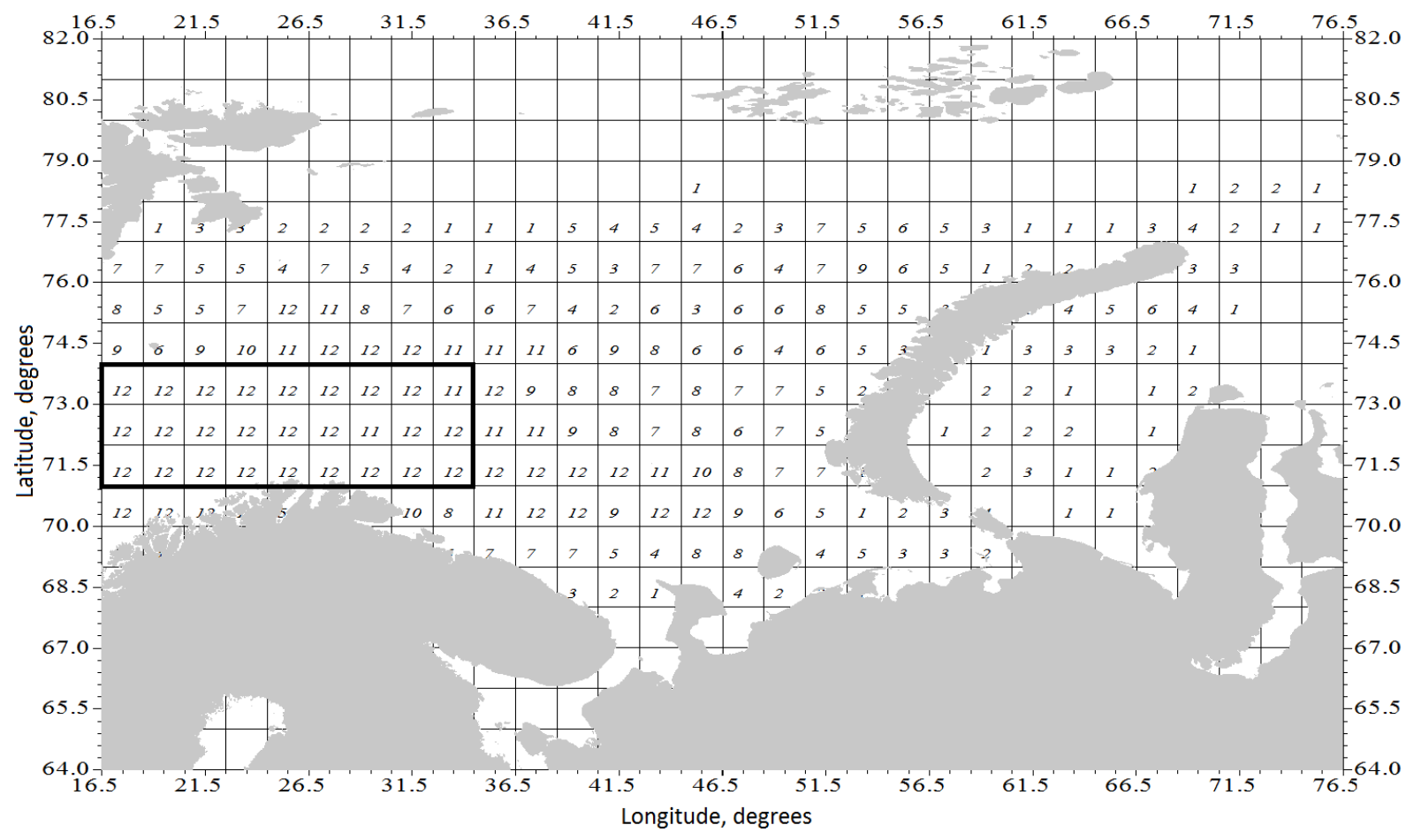

Figure 6. The number of months of year in which the measurements of water temperature at a surface in grid cells with steps $2^{\circ}$ on longitude and $1^{\circ}$ on latitude were carried out. The frame specifies the region for calculation of the intra-annual variation of water temperature. 


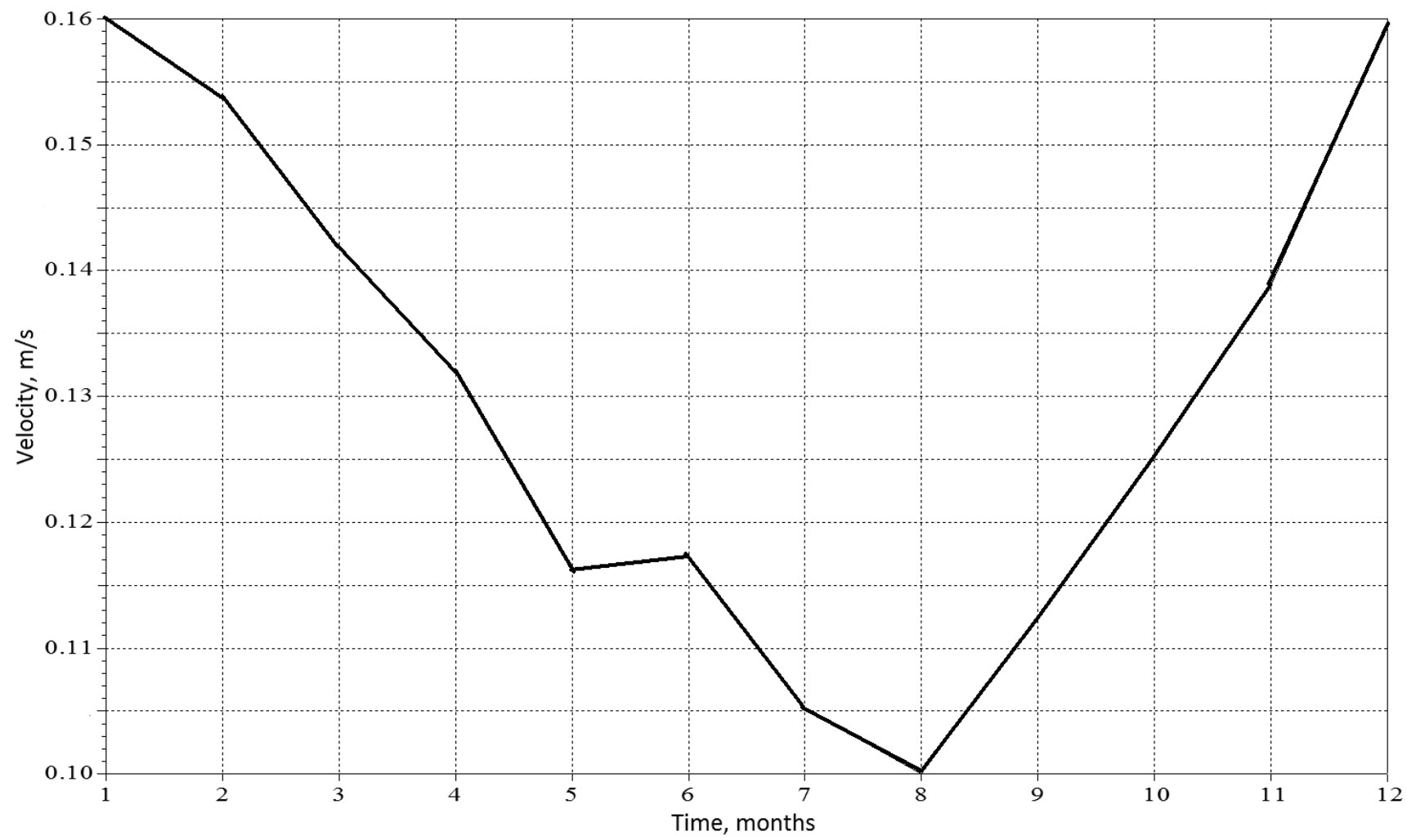

Figure 7. The intra-annual variation of a velocity module of actual currents at the depth of $15 \mathrm{~m}$ according to the data of drifting buoys averaged over the south-western region of the Barents Sea.

the current velocity vector was carried out. As it can be seen, the zone of the largest coverage by drifter observations of currents over months of a year (from 10 to 12 months) corresponds to the south-western area of the Barents Sea, ice-free due to the warm North Cape current.

Figure 6 shows the distribution over cells of the same grid of the number of months of the year in which measurements of water temperature at the surface were carried out. As it can be seen, the zone of the largest coverage by temperature measurements over months of a year is greater than the zone of the largest coverage by observations of the current velocities, but also mainly corresponds to the south-western region of the Barents Sea.

The information in Figure 3 Figure 6 about the coverage of the considered area by drifter observations is useful for planning further observations of currents and water temperature for the purpose of rational deployments of drifters in Barents and Kara Seas.

As drifters are intended for work on open water, these plans should reflect the specific ice situation in both seas, satellite monitoring of which was carried out long ago. According to long-term historical data, in addition to the seasonal course in which the ice cover reaches the greatest distribution in April and the lowest - at the end of August, also inter-annual variability is great. Therefore, in different years and months it can be expected that this or that region in both seas is either completely free from ice, or, on the contrary, is entirely in ice cover zone.

\section{Intra-Annual Variations of Intensity of Subsurface Currents and Surface Temperature}

Existence of observations in all months of a calendar year in many locations in the south-western region of the Barents Sea (Figure 5 and Figure 6 ) provides a basis for calculations of intra-annual variations of the measured parameters. In the period from January 1992 to March 2016136 drifters crossed the region with coordinates of $16.5-34.5^{\circ} \mathrm{E}, 71-74^{\circ} \mathrm{N}$ (this region is marked in Figure 5 and Figure 6 by the frame).

All values of velocity module and water temperature along trajectories of these 136 drifters, interpolated on a six-hour time step, were averaged within the specified region for each month. For more than 24 years of observations, there turned out to be quite a lot interpolated values within the specified region-from 1185 to 3706 for the module of velocity (and much more for the water temperature) depending on a month. Figure 7 shows the intra-annual variation of the module of velocity of actual currents at the depth of $15 \mathrm{~m}$ and Figure 8 - the intra-annual variation of the surface water temperature, averaged monthly and over the specified region.

According to Figure 7 in winter in the south-western part of the Barents Sea the currents get stronger probably due to the strengthening of winds, and weaken in summer. According to Figure 8 sea surface temperature is minimal in April 


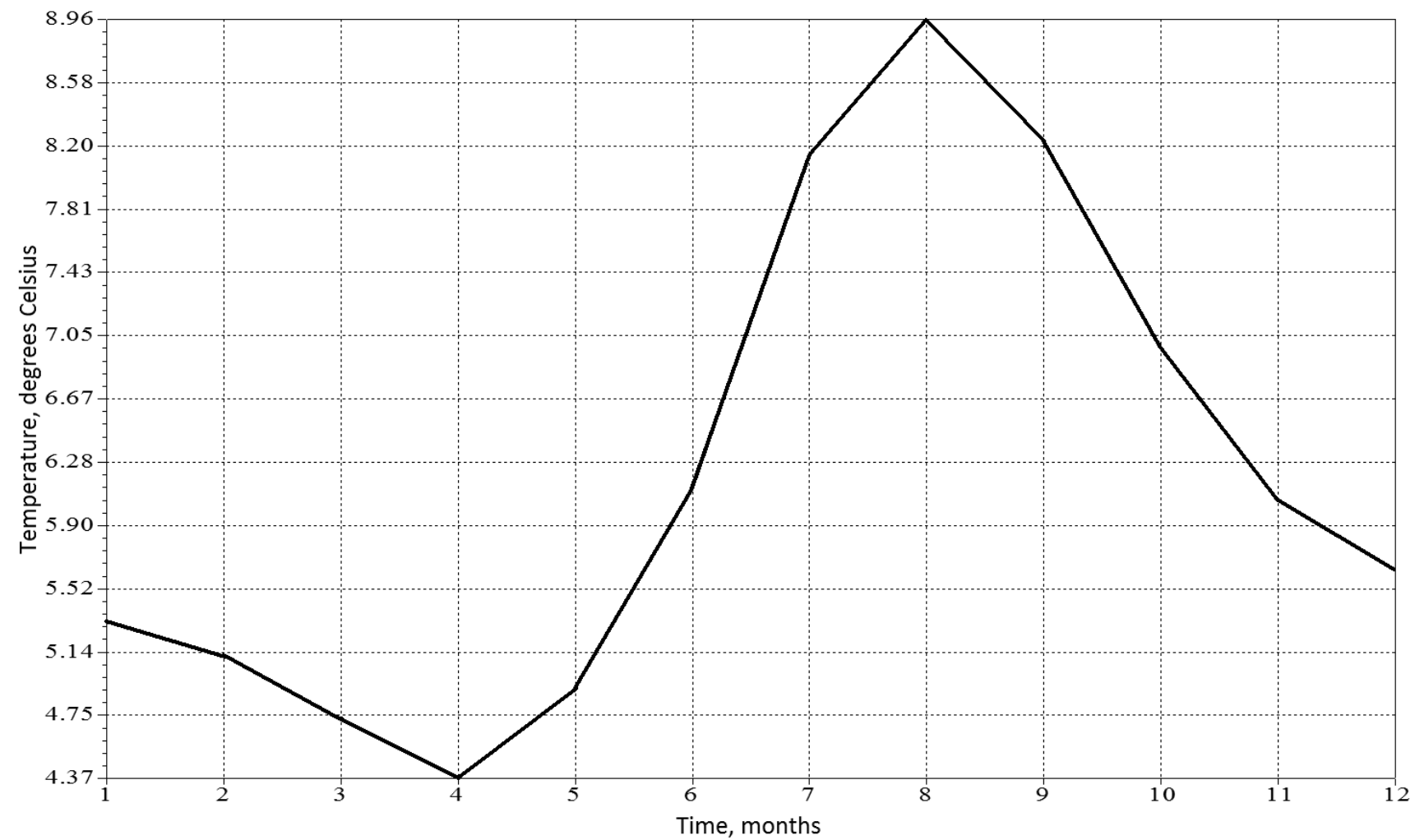

Figure 8. The intra-annual variation of water temperature at the surface according to the data of drifting buoys averaged over the south-western region of the Barents Sea.

and reaches maximum in August. There is an interesting coincidence of time of minimum of the average velocity module of currents with water temperature peak at a surface in August.

Reproducibility of these results can serve as a test of quality of currently used numerical models of the Barents Sea.

\section{Conclusions}

In conclusion, it should be stated that drifter observations in the Russian part of the Barents Sea and also in the Kara Sea were carried out very little, not enough to build maps of average currents, nor to calculate the parameters of intraand especially inter-annual variability of currents and water temperature. Calculations of the intra-annual variations of velocity of the actual currents at a depth of $15 \mathrm{~m}$ and the surface water temperature were possible to be made only for the south-western, Norwegian part of the Barents Sea.

The active participation of the Russian Federation in GDP seems reasonable, within which the technology of the satellite locating of drifters, receiving the operational hydrometeorological data from them and their transfer by means of the Global Telecommunication System of the World Meteorological Organization to the national hydrometeorological centers are developed. The production of drifters of the GDP standard has long been established in Sevastopol com- pany "Marlin-Yug" [Tolstosheev et al., 2008. Within GDP the delayed control, edition, interpolation of drifter data and provision of the processed data in open access via the Internet is also carried out. In comparison to numerical models, the drifter observations provide a more precise and reliable information about the actual currents.

Besides the data on currents and water temperature, at present many drifters transmit the data of the atmospheric pressure at a sea surface. In addition, measuring instruments of speed and the direction of wind can be installed on drifters that turns them into floating hydrometeorological stations. But even without the wind data, the operational data on the atmospheric pressure and water temperature at the sea surface which would come from the drifters deployed in the Russian part of the Barents Sea and also in the Kara Sea, could improve weather forecasts over the Russian territory.

\section{References}

Aadlandsvik, B. (1989), A wind-driven model of the Barents Sea, Bergen Scientific Centre Report Series, No. 89114, 20.

Averkiev, A. S., K. A. Klevanny (2010), Simulation of flow in the Barents Sea in connection with the development of the Shtokman gas condensate field, Meteorologija $i$ Gidrologija, No. 11, 44-56. (in Russian)

Arkhipov, B. V., S. K. Popov (1996), Modelling of geostrophic 
and wind-induced currents in the southeastern Barents Sea, Okeanologiya, 36, No. 6, 805-813. (in Russian)

Asplin, L., R. Ingvaldsen, H. Loeng, B. Aadlandsvik (1998) Description and validation of a three-dimensional numerical model of the Nordic and Barents Seas, Fisken og Havet, No. $10, \quad 35$.

Bulushev, M. G., A. N. Sidorova (1994), Calculations of monthly mean circulation in the Barents Sea, Meteorologiya $i$ Gidrologiya, No. 4, 78-86. (in Russian)

Diansky, N., V. Fomin, I. Kabatchenko, V. Gruzinov, Y. Bogdanov (2014), Calculation of currents of the Arctic seas, Proc. State Oceanographic Inst., No. 215, 5-27. (in Russian)

Grodsky, S., R. Lumpkin, J. Carton (2011), Spurious trends in global surface drifter currents, Geophys. Res. Lett., 38, No. L10606, 6.

Ingvaldsen, R., L. Asplin, H. Loeng (1999), Short time variability in the Atlantic inflow to the Barents Sea, ICES C.M., $L: 05,12$.

Loeng, H., S. Sundby, O. Ostensen (1989), Drifting Argos buoys in the Barents Sea, ICES C.M., C:19, 10.

Lumpkin, R., M. Pazos (2007), Measuring surface currents with Surface Velocity Program drifters: The instrument, its data, and some recent results, Lagrangian Analysis and Prediction of Coastal and Ocean Dynamics, A. Griffa et al. (eds.), Chap. 2 p. 39-67, Cambridge Univ. Press, Cambridge, U.K. doi:10.1017/CBO9780511535901.003

Pazan, S. E., P. P. Niiler (2001), Recovery of near-surface velocity from undrogued drifters, J. Atmos. Oceanic Technol. 18, 476-489, doi:10.1175/1520-0426(2001)018<0476:RONSVF $>2.0 . \mathrm{CO} ; 2$
Reverdin, G., C. Frankignoul, E. Kestenare, M. J. McPhaden (1994), Seasonal variability in the surface currents of the equatorial Pacific, J. Geophys. Res., 99, No. C10, 20,32320,344, doi:10.1029/94JC01477

Semenov, G. A., S. V. Chvilev (1996), Numerical modelling of interannual variability of the Barents Sea circulation in summer, Okeanologiya, 36, No. 4, 498-511. (in Russian)

Slagstad, D., K. Stole-Hansen, H. Loeng (1989), Densitydriven currents in the Barents Sea calculated by numerical model, ICES C.M., C:20, 14.

Tolstosheev, A. P., E. G. Lunev, V. S. Motyzhev (2008), Development of means and methods of drifter technology applied to the problem of the Black Sea research, Oceanology, 48, No. 1, 138-146, doi:10.1134/S0001437008010165

Trofimov, A. G. (2000), Numerical Modelling of Water Circulation in the Barents Sea, 42 pp., PINRO, Murmansk. (Preprint, in Russian)

Turet, P., C. H. Pease, R. S. Pritchard, J. E. Overland (1993), Method for Extracting Tidal and Inertial Motion From Argos Ice Buoys Applied to the Barents Sea During CEAREX, NOAA Technical Memorandum ERL PMEL-99, 63 pp., NOAA, USA.

Yakovlev, N. G. (1999), Calculation of monthly mean circulation in the Barents Sea and analysis of its sensitivity to water exchange through the open boundaries, Izvestiya AN, Fizika Atmosphery $i$ Okeana, 35, No. 6, 846-857. (in Russian)

O. P. Nikitin and A. O. Zhukovskaya, Zubov State Oceanographic Institute, Moscow, Russia. (opnikitin@mail.ru) 